\title{
PREFERENSI MUDIK TAHUN 2021 BERDASARKAN SURVEI MUDIK PADA MASA PANDEMI COVID-19
}

\author{
Tri Basuki Joewono \\ Program Studi Teknik Sipil \\ Universitas Katolik Parahyangan \\ Jln. Ciumbuleuit No. 94, Bandung 40141 \\ vftribas@unpar.ac.id \\ Jeanly Syahputri \\ Program Studi Teknik Sipil \\ Universitas Katolik Parahyangan \\ Jln. Ciumbuleuit No. 94, Bandung 40141 \\ jeanlysyahputri@gmail.com
}

\author{
Muhamad Rizki \\ Program Studi Teknik Sipil \\ Institut Teknologi Nasional Bandung \\ Jln. PH Mustofa No. 23, Bandung 40124 \\ muhamadrizki1404@itenas.ac.id \\ Fabianus Sebastian Kevin \\ Program Studi Teknik Sipil \\ Universitas Katolik Parahyangan \\ Jln. Ciumbuleuit No. 94, Bandung 40141 \\ fabianus.kevin@gmail.com
}

\begin{abstract}
The Covid-19 pandemic has changed the way people carry out their daily activities and limit the movement of people including going home (or mudik) in 2020. This study aims to understand the effect of Covid-19 on the intention of travelers to go home in 2021 in Indonesia. The data in this study were obtained from online respondents and analyzed using discriminant analysis. Although there is still uncertainty about when the pandemic will end, this study shows that there are travelers who will continue to go home in 2021, especially those with lower incomes and young people. In addition, the emotional aspect was found to influence the intention to go home in 2021. This study recommends the need for a more detailed health protocol for homecoming travelers who will continue to go home and for cities that become homecoming destinations in 2021. In addition, the improvement of Information and Communication Technology infrastructure in the regions needs to be improved to reduce the desire to go home during the pandemic.
\end{abstract}

Keywords: mudik; Covid-19 pandemic; travel; traveler; health protocol.

\begin{abstract}
Abstrak
Pandemi Covid-19 telah mengubah cara masyarakat melakukan kegiatan sehari-hari dan membatasi pergerakan masyarakat termasuk pada saat mudik tahun 2020. Penelitian ini bertujuan untuk memahami pengaruh Covid19 terhadap intensi pelaku perjalanan untuk melakukan mudik pada tahun 2021 di Indonesia. Data pada studi ini diperoleh dari responden secara online dan dianalisis dengan menggunakan analisis diskriminan. Meskipun masih ada ketidakpastian kapan pandemi berakhir, penelitian ini menunjukkan bahwa terdapat pelaku perjalanan yang tetap akan melakukan mudik pada tahun 2021, khususnya mereka dengan pendapatan yang lebih rendah dan dengan usia muda. Selain itu aspek emosional ditemukan memengaruhi intensi untuk melakukan mudik pada tahun 2021. Studi ini merekomendasikan perlunya protokol kesehatan untuk mudik yang lebih rinci untuk para pelaku perjalanan yang tetap akan melakukan mudik serta untuk bagi kota-kota yang menjadi tujuan mudik pada tahun 2021. Selain itu, peningkatan infrastruktur Teknologi Informasi dan Komunikasi di daerah-daerah perlu ditingkatkan untuk mengurangi keinginan melakukan mudik pada masa pandemi.
\end{abstract}

Kata-kata kunci: mudik; pandemi Covid-19; perjalanan; pelaku perjalanan; protokol kesehatan.

\section{PENDAHULUAN}

Sejak kemunculan pertamanya di Wuhan, China, pada akhir tahun 2019, Coronavirus Disease (Covid-19) telah menjadi pandemi global, dengan jumlah kasus yang mencapai lebih dari 15 juta orang pada Agustus 2020. Pandemi, yang penyebarannya dipengaruhi oleh 
interaksi antarmanusia, ini telah membuat sistem-sistem ekonomi, kesehatan, dan pemerintahan terguncang (Musselwhite et al., 2020). Dalam merespon hal tersebut, pemerintah menetapkan pembatasan sosial dan aktivitas (Honey-Roses et al., 2020), yang sangat berpengaruh pada kegiatan perjalanan di berbagai moda angkutan, yaitu angkutan darat, angkutan laut, dan angkutan udara (Zhang dan Hayashi, 2020).

Pemerintah Republik Indonesia mengumumkan kasus pertama Covid-19 pada awal Maret 2019, disertai keputusan penerapan Pembatasan Sosial Berskala Besar (PSBB) (Djalante et al., 2020). Penerapan kebijakan ini telah memengaruhi mobilitas masyarakat Indonesia, dengan yang terpengaruh besar adalah kegiatan mudik, yang umumnya dilakukan oleh masyarakat di Indonesia menjelang Idul Fitri (Prasetyo dan Sofyan, 2020). Perjalanan mudik ini merupakan perjalanan ritual yang unik dan dilakukan oleh masyarakat Indonesia, serta umumnya menarik jutaan orang (Yulianto, 2012). Saat pandemi Covid-19 tahun 2020, perjalanan mudik ini sangat berkurang, karena adanya penerapan kebijakan pembatasan pergerakan di kota-kota Indonesia.

Pembatasan pergerakan telah memengaruhi kebutuhan individu untuk beraktivitas, yang ditujukkan untuk memenuhi kebutuhan kesehatan mental dan emosional (Ettema et al., 2010). Berbagai masalah mental tersebut telah muncul pada pandemi ini, seperti stress dan frustasi. Beberapa studi menunjukkan bahwa masalah ini akan berlanjut walaupun pandemi berakhir (Brooks et al., 2020; Campbell, 2020). Pengaruh ini juga berdampak pada partisipasi seseorang untuk melakukan perjalanan di masa mendatang, termasuk untuk perjalanan mudik, karena mudik dilakukan dalam rangka memenuhi kebutuhan mental dan emosional juga (Prasetyo dan Sofyan, 2020).

Studi tentang pengaruh Covid-19 pada karakteristik perjalanan pada umumnya masih sangat terbatas (De Vos, 2020). Di sisi lain studi tentang mudik sangat penting dilakukan karena merupakan perjalanan yang dilakukan oleh banyak masyarakat Indonesia secara reguler setiap tahun. Pemahaman tentang perjalanan mudik di masa mendatang yang didasarkan pada kondisi pandemi sangat penting untuk merumuskan kebijakan manajemen perjalanan mudik mendatang sehingga kemacetan dan faktor negatif lainnya dapat diatasi. Dengan urgensi tersebut, studi ini bertujuan untuk memahami perilaku perjalanan mudik pada tahun 2021. Secara spesifik pada penelitian dilakukan analisis terhadap intensi mudik pada tahun 2021 dengan mempertimbangkan alasan mudik, aspek kesehatan mental saat pandemi 2020, dan aspek sosio demografi.

Makalah ini dibagi menjadi 4 bagian. Setelah pendahuluan, di bagian 2 dijelaskan metodologi pengumpulan data dan statistika deskriptif untuk variabel kunci. Kemudian pada bagian 3, disajikan analisis klasifikasi intensi mudik pada tahun 2021 dan di bagian 4 disajikan hasil analisis dan kesimpulan.

\section{PENGUMPULAN DATA}

\section{Perumusan Kuesioner}

Kuesioner dirumuskan untuk mendapatkan informasi terkait keputusan atau intensi pelaku perjalanan untuk mudik pada tahun 2021. Dalam rangka menginvestigasi faktor- 
faktor yang memengaruhinya, pertanyaan tentang kesehatan mental (Brooks et al., 2020) dan alasan mudik (Prasetyo dan Sofyan, 2020) diakomodasi dalam kuesioner serta pertanyaan tentang karakteristik demografi dan lokasi spasial.

Pada bagian pertama, responden diberi pertanyaan tentang alasan dan keputusan mudik pada tahun 2020, yang merupakan tahun terjadinya pandemi Covid-19. Alasan mudik yang ditanyakan terdiri atas alasan tradisi, liburan, rindu kampung halaman, senang berpergian, dan waktu silaturahmi, dengan skala jawaban likert dari 1, yang menandakan sangat tidak setuju, sampai dengan 5, yang menandakan sangat setuju. Pada bagian kedua responden ditanya perasaannya saat pandemi, dengan 9 pertanyaan, yaitu frustrasi, depresi, tidak sabar, lelah, khawatir, bosan, tidak produktif, jengkel, dan pengalaman terburuk. Skala jawaban pada perasaan saat pandemi juga menggunakan skala likert, dengan 1 menandakan sangat tidak setuju dan 5 menandakan sangat setuju. Pada bagian berikutnya ditanyakan tentang intensi untuk melakukan mudik pada tahun 2021, dengan 4 pilihan jawaban, yaitu tidak, tidak tahu, ya, dan ya jika ada vaksin. Selanjutnya di bagian akhir responden ditanya tentang sosio demografi.

Selanjutnya kuesioner dibentuk secara online dengan platform formulir Google dan formulir diubah menjadi tautan web. Kuesioner didistribusikan dengan bantuan surveyor yang mengirim link kuesioner pada potensi responden dengan bantuan media-media sosial, yaitu Facebook, Instagram, Twitter, Line, dan WhatsApp, sehingga interaksi tatap muka selama survei dapat dihindari. Survei dilaksanakan secara daring selama 2 hari, dari tanggal 7 Juli 2020. Secara keseluruhan, terdapat 424 responden yang terkumpul dari seluruh Indonesia. Setelah dilakukan sortir terhadap seluruh data, diperoleh 421 data yang valid, yaitu data yang merupakan jawaban survei dari responden yang melakukan mudik pada Idul Fitri tahun sebelumnya.

Tabel 1 Karakteristik Demografi Responden

\begin{tabular}{|c|c|c|c|c|c|}
\hline & Variabel & $(\%)$ & \multicolumn{2}{|c|}{ Variabel } & $(\%)$ \\
\hline \multicolumn{3}{|c|}{ Sosio-demografi } & \multicolumn{3}{|c|}{ Sosio-demografi } \\
\hline \multirow{5}{*}{ Usia } & $<18$ tahun & 19,7 & \multirow{2}{*}{ Gender } & \multirow{2}{*}{$\begin{array}{l}\text { Pria } \\
\text { wanita }\end{array}$} & 52,0 \\
\hline & $18-25$ tahun & 49,6 & & & 48,0 \\
\hline & 26-40 tahun & 20,2 & \multirow{8}{*}{ Pendapatan } & $<1$ juta Rupiah & 4,0 \\
\hline & $41-60$ tahun & 10,5 & & 1-2.5 juta Rupiah & 8,1 \\
\hline & $>60$ tahun & 0,0 & & 2.6-5 juta Rupiah & 14,5 \\
\hline \multirow{8}{*}{ Pekerjaan } & Mahasiswa/pelajar & 61,5 & & 6-7,5 juta Rupiah & 22,6 \\
\hline & PNS & 3,6 & & 7,6-10 juta Rupiah & 10,0 \\
\hline & Karyawan kantor swasta & 15,9 & & 10-15 juta Rupiah & 13,1 \\
\hline & Wiraswasta & 10,9 & & 15-20 juta Rupiah & 7,1 \\
\hline & Ibu Rumah Tangga & 2,4 & & $>20$ juta Rupiah & 10,7 \\
\hline & Pekerja bebas/harian & 4,0 & \multirow{3}{*}{ Pendidikan } & SD/SMP/SMA & 60,6 \\
\hline & Pensiunan & 0,5 & & $\mathrm{D} 3 / \mathrm{D} 4 / \mathrm{S} 1$ & 37,3 \\
\hline & Tidak bekerja & 1,2 & & $\mathrm{~S} 2 / \mathrm{S} 3$ & 2,1 \\
\hline
\end{tabular}

\section{Deskripsi Data}

Tabel 1 menyajikan karakteristik demografi responden. Sebagian besar responden berada pada usia belajar, yaitu 49,6\% pada rentang 18-25 tahun. Hal ini diperkuat dengan 
kenyataan bahwa 61,5\% responden adalah mahasiswa atau pelajar. Dari 61,5\% tersebut, sebagian besar berada pada jenjang pendidikan dasar, yaitu SD, SMP, atau SMA, dengan jumlah $60,6 \%$ dari total responden. Selain itu, responden didominasi oleh laki-laki, yaitu sebanyak $52 \%$.

\section{ANALISIS}

\section{Karakteristik Kesehatan Mental Pelaku Perjalanan}

Pada Tabel 2 dapat dilihat bahwa para responden merasakan beragam perasaan selama masa pandemi Covid-19. Lebih dari setengah responden (50,6\%) merasa tidak sabar dan berharap pandemi ini segera berakhir. Sebaliknya, sangat sedikit responden yang merasa frustasi dan depresi, namun tak sedikit pula yang merasa jengkel, lelah, dan tidak produktif.

Tabel 2 Perasaan Responden Saat Pandemi Covid-19

\begin{tabular}{lrrrrr}
\hline \multirow{2}{*}{ Perasaan Saat Pandemi Covid-19 } & \multicolumn{5}{c}{ Proporsi (\%) } \\
\cline { 2 - 6 } & STS & \multicolumn{1}{c}{ TS } & \multicolumn{1}{c}{ N } & S & \multicolumn{1}{c}{ SS } \\
\hline Frustasi & 4,8 & 23,0 & 33,5 & 34,0 & 4,8 \\
Depresi & 7,8 & 24,7 & 32,1 & 30,4 & 5,0 \\
Khawatir & 2,9 & 4,0 & 14,7 & 56,3 & 22,1 \\
Bosan & 4,3 & 4,5 & 14,0 & 49,9 & 27,3 \\
Tidak produktif & 6,9 & 12,1 & 19,7 & 45,4 & 15,9 \\
Jengkel & 4,8 & 5,2 & 18,5 & 50,8 & 20,7 \\
Lelah & 4,8 & 6,9 & 21,4 & 49,6 & 17,3 \\
Tidak sabar untuk cepat berakhir & 3,6 & 0,2 & 5,7 & 39,9 & 50,6 \\
Pengalaman terburuk saya & 7,4 & 5,7 & 21,6 & 39,2 & 26,1 \\
\hline STS = Sangat tidak setuju; TS = Tidak setuju; N $=$ Netral; S = Setuju; \\
SS = Sangat setuju & \multicolumn{5}{c}{}
\end{tabular}

\section{Karakteristik Alasan Mudik Pelaku Perjalanan}

Pada Tabel 3 terlihat bahwa sebagian besar responden menyatakan bahwa mereka melakukan mudik dengan beragam alasan. Terdapat $56,8 \%$ responden yang memilih setuju untuk memanfaatkan mudik untuk berlibur atau refreshing. Selain itu, yang menjadi alasan kuat lainnya adalah untuk bersilahturahmi dengan sanak saudara, dengan 38,2\% responden yang memilih sangat setuju. Alasan-alasan itu masih tetap menjadi motivasi para responden untuk melakukan mudik tahun ini. Terlihat bahwa 47,8\% responden tetap setuju memilih alasan mudik sebagai sarana berlibur dan refreshing. Selain itu, 30,4\% responden masih sangat setuju jika mudik tahun ini merupakan kesempatan untuk bersilahturahmi dengan sanak saudara.

\section{Model Klasifikasi Intensi Mudik Tahun 2021}

Model klasifikasi intensi mudik tahun 2021 dibentuk dengan menggunakan analisis diskriminan. Variabel terikat pada model diskriminan, yaitu intensi mudik tahun 2021, dideskripsikan pada Tabel 4. Sebagian besar (28,3\%) responden masih belum menentukan apakah mereka akan mudik. Namun tak sedikit pula yang telah menentukan bahwa mereka 
akan mudik tahun depan apapun yang terjadi. Hal menarik juga terjadi, dengan seperempat responden memilih untuk tidak mudik tahun depan.

Tabel 3 Alasan Responden Mudik

\begin{tabular}{lccccc}
\hline \multirow{2}{*}{ Saya mudik karena... } & \multicolumn{5}{c}{ Proporsi (\%) } \\
\cline { 2 - 6 } & STS & TS & N & S & SS \\
\hline Sebagai media saya liburan atau refreshing & 5,7 & 5,2 & 17,6 & 56,8 & 14,7 \\
Rindu kampung halaman & 4,8 & 5,9 & 49,5 & 47,7 & 22,1 \\
Rindu orang tua atau saudara & 4,8 & 4,8 & 15,0 & 45,6 & 29,9 \\
Senang berpergian & 5,2 & 5,2 & 19,7 & 49,2 & 20,7 \\
Merupakan tradisi keluarga saya & 4,8 & 4,8 & 19,0 & 42,8 & 28,7 \\
Waktu yang tepat bersilaturahmi dengan sanak & 5,0 & 3,1 & 11,9 & 41,8 & 38,2 \\
saudara & & & & &
\end{tabular}

STS = Sangat tidak setuju; TS = Tidak setuju N = Netral; S = Setuju; SS = Sangat setuju

Tabel 4 Intensi Mudik Tahun 2021

\begin{tabular}{lcccc}
\hline $\begin{array}{c}\text { Rencana untuk Mudik } \\
\text { Tahun 2021 }\end{array}$ & $\begin{array}{c}\text { Tidak } \\
\text { Mudik }\end{array}$ & $\begin{array}{c}\text { Belum } \\
\text { Memutuskan }\end{array}$ & $\begin{array}{c}\text { Akan } \\
\text { Mudik }\end{array}$ & $\begin{array}{c}\text { Mudik Jika Vaksin } \\
\text { Telah Ada }\end{array}$ \\
\hline Proporsi $(\%)$ & 25,9 & 28,3 & 21,1 & 24,7 \\
\hline
\end{tabular}

Analisis diskriminan dengan variabel terikat intensi mudik tahun 2021 ditampilkan pada Tabel 5. Dalam melakukan review kualitas model, dilakukan evaluasi nilai korelasi canonical di setiap fungsi yang menjelaskan bahwa model dapat menjelaskan 10-15\% variasi. Nilai kesesuaian klasifikasi pada model menunjukan nilai lebih besar dari 50,4\%.

Interpretasi model diskriminan dilakukan dengan fungsi pusat grup atau Function of Group Centroid (FGC), yang memisahkan 2 pilihan. Intepretasi dilakukan dengan mengevaluasi pilihan dengan nilai paling positif dan negatif serta loading pada structural matrix yang lebih besar dari 0,3. Dari 4 grup intensi mudik tahun 2021, dihasilkan 3 fungsi. Fungsi pertama memisahkan responden yang berintensi mudik dan responden yang tidak akan mudik. Fungsi kedua memisahkan grup pelaku perjalanan yang belum memutuskan mudik dan tidak akan mudik, dan grup ketiga memisahkan pelaku perjalanan yang belum memutuskan mudik dan yang akan mudik jika terdapat vaksin.

Matrik struktur pada fungsi pertama menujukkan bahwa variabel pendapatan kurang dari 2,5 juta rupiah dan alasan rindu orang tua cenderung berasosiasi pada pelaku perjalanan yang akan mudik daripada yang belum memutuskan mudik. Sedangkan pelaku perjalanan yang memiliki saudara yang tinggal bersama lebih banyak cenderung belum memutuskan mudik daripada akan mudik.

Pada fungsi kedua ditemukan bahwa jumlah ketersediaan mobil yang tinggi dan pendapatan lebih besar dari 10 juta berasosiasi dengan grup yang belum memutuskan mudik daripada yang tidak akan mudik. Fungsi kedua juga menunjukkan bahwa responden yang merasakan tidak produktif saat pandemi cenderung tidak akan mudik pada tahun 2021. 


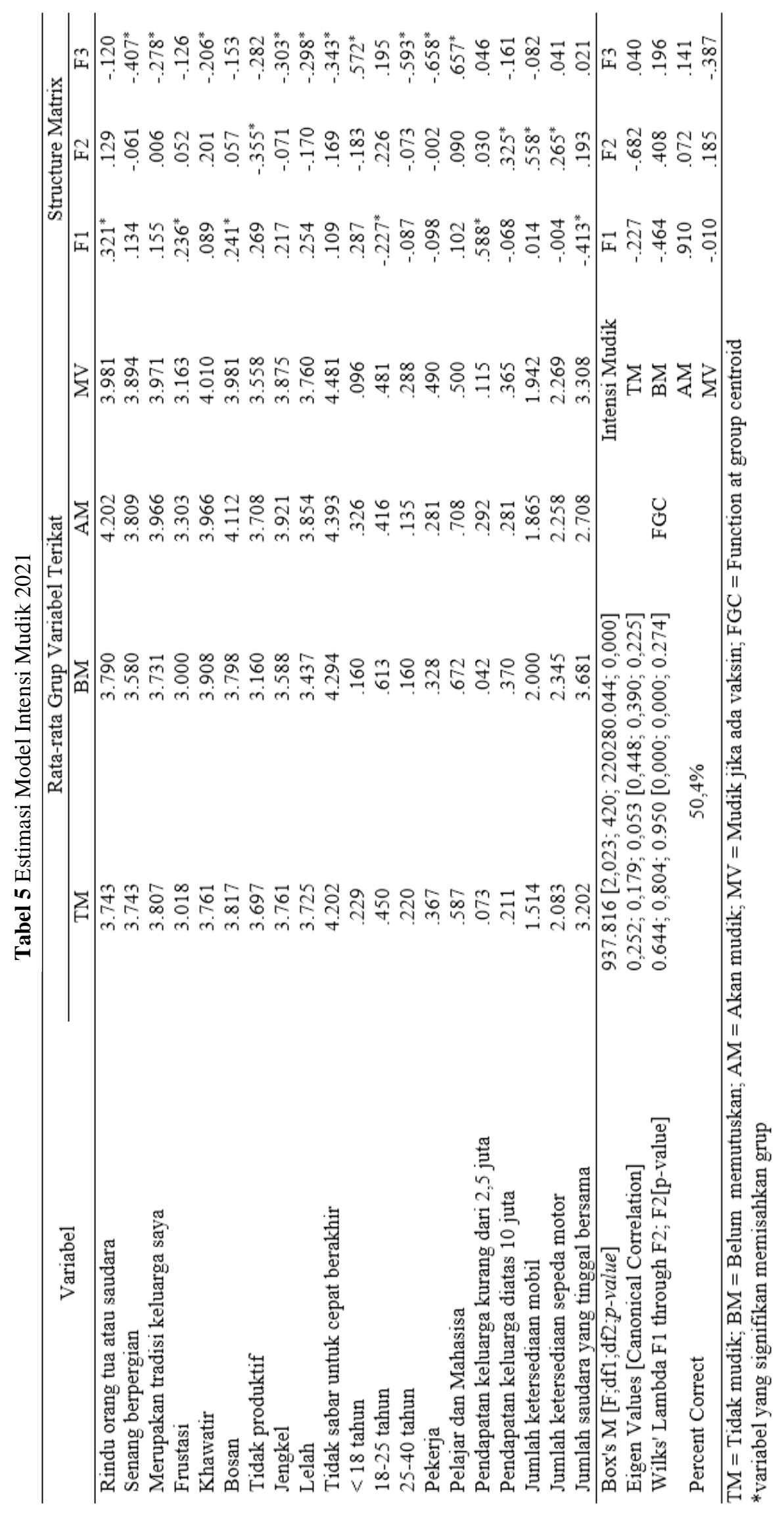


Fungsi terakhir yang memisahkan antara grup pelaku perjalanan yang belum memutuskan untuk mudik dan yang akan mudik jika ada vaksin ditemukan terpisah berdasarkan alasan senang berpergian, perasaan jengkel dan tidak sabar saat pandemi, usia 25-40 tahun, pekerja, dan mahasiswa. Pelaku perjalanan dengan usia 25-40 tahun, pekerja, orang yang mengalami perasaan jengkel dan tidak sabar untuk menunggu Covid-19 berakhir, dan orang yang senang berpergian cenderung akan memutuskan untuk mudik jika vaksin telah tersedia. Sedangkan pelajar dan mahasiswa serta mereka yang berusia kurang dari 18 tahun cenderung belum memutuskan untuk mudik.

\section{DISKUSI DAN KESIMPULAN}

Covid-19 telah mengubah bagaimana masyarakat melakukan kegiatan sehari-hari dan membatasi pergerakan masyarakat, termasuk pada saat mudik tahun 2020. Penelitian ini bertujuan untuk memahami bagaimana Covid-19 berpengaruh terhadap intensi pelaku perjalanan untuk melakukan mudik pada tahun 2021 di Indonesia.

Deskripsi responden menunjukkan bahwa terdapat variasi intensi dalam melakukan mudik, mulai dari keputusan untuk mudik hingga keputusan untuk tidak mudik. Variabel yang memengaruhi keputusan tersebut diinvestigasi dalam analisis diskriminan dengan variabel bebas karakteristik sosio demografi, alasan penggunaan, dan perasaan saat pandemi.

Model diskriminan menujukkan bahwa variabel sosio-demografi merupakan salah satu variabel penjelas intensi untuk mudik pada tahun 2021. Pelaku perjalanan dengan pendapatan keluarga kurang dari 2,5 juta rupiah cenderung akan mudik. Sedangkan pelaku perjalanan dengan pendapatan keluarga tinggi cenderung dengan grup yang belum memutuskan untuk mudik. Hal ini diprediksi pada keluarga dengan penghasilan lebih rendah cenderung memiliki tradisi yang lebih besar untuk melakukan mudik dan memiliki pertimbangan yang lebih fleksibel untuk melakukan mudik. Sedangkan pelaku perjalanan dengan pendapatan yang lebih tinggi cenderung berhati-hati dalam melakukan mudik, dengan keputusan untuk mudik dibuat jika vaksin sudah tersedia. Sementara itu, pelajar cenderung belum memutuskan untuk mudik. Sejalan dengan pendapatan tinggi, ketersediaan kendaraan pribadi yang tinggi berasosiasi dengan grup yang belum memutuskan untuk mudik.

Alasan untuk mudik diketahui memengaruhi intensi untuk mudik. Alasan rindu orang tua cenderung berasosiasi pada pelaku perjalanan yang akan mudik daripada yang belum memutuskan mudik. Temuan ini menandakan perasaan emosional terhadap anggota keluarga sangat memengaruhi keputusan mudik daripada variabel lainnya. Jumlah keluarga atau saudara yang tinggal bersama cenderung masuk pada grup yang belum memutuskan mudik. Diduga bahwa dengan semakin banyak anggota keluarga, kebutuhan untuk mudik akan berkurang karena keluarga berkumpul pada satu rumah. Pelaku perjalanan yang merasakan perasaan jengkel dan tidak sabar untuk menunggu pandemi berakhir cenderung 
akan melakukan mudik asal vaksin telah tersedia. Hasil ini menunjukkan bahwa meskipun orang merasakan ketidaksabaran dan perasaan jengkel, dalam memutuskan untuk mudik, pelaku perjalanan tetap memilih membuat keputusan dengan risiko rendah, yaitu dengan tersedianya vaksin.

Temuan penelitian ini merekomendasikan beberapa kebijakan dalam rangka memitigasi efek negatif mudik pada tahun 2021. Belum adanya kepastian akan berakhirnya pandemi Covid-19, penelitian ini menunjukkan bahwa terdapat pelaku perjalanan yang tetap akan melakukan mudik pada tahun 2021, khususnya pada segmentasi pelaku perjalanan dengan pendapatan yang lebih rendah dan pada usia muda. Dengan hal tersebut, sebelum periode mudik, Pemerintah perlu mempersiapkan protokol mudik yang sesuai dengan anjuran pembatasan sosial WHO (WHO, 2020). Selain itu, edukasi protokol inipun sangat penting untuk diterapkan di lokasi-lokasi tujuan mudik yang umumnya merupakan perkotaan dengan populasi lebih rendah atau pedesaan, sehingga tidak terjadi penyebaran pada lokasi-lokasi tujuan tersebut. Selain itu, temuan tentang alasan mudik menunjukkan bahwa alasan emosional sangat berperan dalam intensi untuk mudik. Dengan adanya perkembangan teknologi, pemerintah dan swasta dapat meningkatkan infrastruktur Teknologi Informasi dan Komunikasi (TIK) di daerah-daerah untuk meningkatkan aksesibilitas telekomunikasi. Jika kebutuhan emosional yang terkait dengan aktivitas mudik dapat difasilitasi, kemungkinan mudik dapat dimitigasi pada masa pandemi, khususnya pada segmentasi pelaku perjalanan yang belum memutuskan atau masih memikirkan untuk mudik.

Penelitian ini juga memiliki beberapa keterbatasan yang dapat menjadi dasar untuk penelitian lebih lanjut. Penelitian ini hanya melakukan investigasi terhadap intensi untuk mudik pada tahun 2021 tanpa melakukan inventarisasi karakteristik perjalanan mudik secara lebih detail. Studi lebih lanjut akan bermanfaat untuk memahami perilaku secara lebih komprehensif sehingga rekomendasi kebijakan dapat tersusun dengan lebih fokus dan lebih terarah.

\section{UCAPAN TERIMAKASIH}

Penelitian ini dibiayai oleh hibah pendamping World Class Researcher (WCR) Universitas Katolik Parahyangan. Para peneliti berterimakasih pada pihak-pihak yang membantu dalam pengumpulan data.

\section{DAFTAR PUSTAKA}

Brooks, S.K., Webster, R.K., Smith, L.E., Woodland, L., Wessely, S., Greenberg, N., dan Rubin, G.J. 2020. The Psychological Impact of Quarantine and How to Reduce It: Rapid Review of the Evidence. The Lancet, 395 (10227): 912-920. 
Campbell, D. 2020. UK Lockdown Causing "Serious Mental Illness in First-Time Patients. The Guardian. (Online), (http://www.theguardian.com/society/2020/may/16/uk-lock down-causing-serious-mental-illness-in-first-time-patients, diakses 28 Mei 2020).

Chen, H., Guo, J., Wang, C., Luo, F., Yu, X., Zhang, W., Li, J., Zhao, D., Xu, D., Gong, Q., Liao, J., Yang, H., Hou, W., dan Zhang, Y. 2020. Clinical Characteristics and Intrauterine Vertical Transmission Potential of Covid-19 Infection in Nine Pregnant Women: A Retrospective Review of Medical Records. The Lancet, 395 (10226), 809815.

De Vos, J. 2020. The Effect of Covid-19 and Subsequent Social Distancing on Travel Behavior. Transportation Research Interdisciplinary Perspectives, 5, 100121.

Djalante, R., Lassa, J., Setiamarga, D., Sudjatma, A., Indrawan, M., Haryanto, B., Mahfud, C., Sinapoy, M.S., Djalante, S., Rafliana, I., Gunawan, L.A., Surtiari, G.A.K., dan Warsilah, H. 2020. Review and analysis of current responses to Covid-19 in Indonesia: Period of January to March 2020. Progress in Disaster Science, 6, 100091.

Ettema, D., Gärling, T., Olsson, L.E., dan Friman, M. 2010. Out-of-Home Activities, Daily Travel, and Subjective Well-Being. Transportation Research Part A: Policy and Practice, 44 (9): 723-732.

Honey-Roses, J., Anguelovski, I., Bohigas, J., Chireh, V., Daher, C., Konijnendijk, C., Litt, J., Mawani, V., McCall, M., Orellana, A., Oscilowicz, E., Sánchez, U., Senbel, M., Tan, X., Villagomez, E., Zapata, O., dan Nieuwenhuijsen, M. 2020. The Impact of Covid-19 on Public Space: A Review of the Emerging Questions - Design, Perceptions and Inequities. Cities \& Health.

Musselwhite, C., Avineri, E., dan Susilo, Y. 2020. Editorial JTH 16-The Coronavirus Disease Covid-19 and Implications for Transport and Health. Journal of Transport dan Health, 16, 100853.

Prasetyo, D.B. dan Sofyan, L. 2020. Altering Intention to Mudik during Covid-19 Pandemic: A Salient Cue and Simple Reminder Treatment (SSRN Scholarly Paper ID 3595007). Social Science Research Network. (Online), (https://doi.org/10.2139/ssrn.3595007, diakses 22 Mei 2020).

World Health Organization. 2020. Technical guidance publications. (Online), (https://www. who.int/emergencies/diseases/novel-coronavirus-2019/technical-guidance-publications, diakses 25 Mei 2020).

Yulianto, V.I. 2012. Is the Past in Another Country? A Case Study of Rural-Urban Affinity on Mudik Lebaran in Middle Java. Journal of Indonesian Social Sciences and Humanities, 4: 49-64.

Zhang, J. dan Hayashi, Y. 2020. Impacts of Covid-19 on the Transport Sector and Measures as Well as Recommendations of Policies and Future Research: Analyses Based on a 
World-Wide Expert Survey (SSRN Scholarly Paper ID 3611806). Social Science Research Network. (Online), (https://papers.ssrn.com/abstract=3611806, diakses 11 Juni 2020). 